\title{
Emerging Parvoviruses in Domestic Cats
}

\author{
Paolo Capozza, Vito Martella (D), Canio Buonavoglia (D) and Nicola Decaro *(D) \\ Department of Veterinary Medicine, University of Bari Aldo Moro, 70010 Valenzano, Italy; \\ paolo.capozza@uniba.it (P.C.); vito.martella@uniba.it (V.M.); canio.buonavoglia@uniba.it (C.B.) \\ * Correspondence: nicola.decaro@uniba.it; Tel.: +39-0804679832
}

check for

updates

Citation: Capozza, P.; Martella, V.; Buonavoglia, C.; Decaro, N. Emerging Parvoviruses in Domestic Cats. Viruses 2021, 13, 1077. https://doi.org/10.3390/v13061077

Academic Editor: Julia A. Beatty

Received: 17 May 2021

Accepted: 4 June 2021

Published: 4 June 2021

Publisher's Note: MDPI stays neutral with regard to jurisdictional claims in published maps and institutional affiliations.

Copyright: (c) 2021 by the authors. Licensee MDPI, Basel, Switzerland. This article is an open access article distributed under the terms and conditions of the Creative Commons Attribution (CC BY) license (https:// creativecommons.org/licenses/by/ $4.0 /)$.

\begin{abstract}
Parvovirus infections in cats have been well known for around 100 years. Recently, the use of molecular assays and metagenomic approaches for virus discovery and characterization has led to the detection of novel parvovirus lineages and/or species infecting the feline host. However, the involvement of emerging parvoviruses in the onset of gastroenteritis or other feline diseases is still uncertain.
\end{abstract}

Keywords: cat; emerging parvoviruses; protoparvoviruses; bocaparvoviruses; chaphamaparvoviruses

\section{Introduction}

Parvoviridae is a large and remarkably diverse family of small (22-30 nm in diameter), non-enveloped, icosahedral viruses. The parvoviral genome is a positive-sense singlestranded (ss) DNA (4.5-5.5 kb), with complex hairpin-like structures at the $5^{\prime}$ and $3^{\prime}$ ends [1-3]. The coding region of the genome contains two major expression cassettes, with open reading frames (ORFs) on the left-hand side giving rise to non-structural (NS) proteins (ORF1), whereas mRNA populations responsible for translating structural proteins (VPs) are transcribed from the right-hand cassette (ORF2) [1,2,4,5].

In recent years, using molecular assays and metagenomic approaches for virus discovery and characterization, different research groups have detected novel lineages and species of parvoviruses in cats, leading to a change in the classification of the family Parvoviridae $[1,2,4,6]$. Indeed, according to the classification criteria of the International Committee on Taxonomy of Viruses (ICTV), the Parvoviridae family is currently divided into three subfamilies: Parvovirinae and Densovirinae, which infect vertebrates and arthropods, respectively, and the new subfamily Hamaparvovirinae, which infects both $[1-4,6]$ (Table 1).

Parvoviruses have a large host spectrum, spanning from invertebrates to mammals $[2,7,8]$. Since the first identification in 1928 from the fecal samples of cats with gastroenteritis $[9,10]$, feline panleukopenia virus (FPV), currently included in the species Carnivore Protoparvovirus 1 of the genus Protoparvovirus [1], has been causing the most important parvoviral disease in cats. All members of the family Felidae are probably susceptible to infection with FPV, which occurs worldwide. Other carnivores of the families Viverridae, Procyonidae, and Mustelidae also are susceptible to infection, although only a smaller number of hosts have been observed to suffer clinical disease, including raccoon (Procyon lotor), mink (genera Mustela and Neovison), and coatimundi (genus Nasua) [7]. Most wild carnivores are also susceptible to the closely related Carnivore Protoparvovirus 1, canine parvovirus (CPV) [11]. In cats, FPV infection causes feline panleukopenia (FPL), a highly contagious, often fatal disease, characterized by acute severe enteritis, dehydration and sepsis due to lymphoid depletion and pancytopenia [12]. Infection spreads rapidly, especially in cells with high mitotic activity, such as bone marrow, lymphoid tissues, and intestinal crypt cells. 
Table 1. Emerging parvoviruses detected in cats and their current classification.

\begin{tabular}{|c|c|c|c|c|c|c|c|}
\hline Subfamily & Genus & Species & Common Names & Country & Year & $\begin{array}{l}\text { Detection } \\
\text { Source }\end{array}$ & Reference \\
\hline \multirow{6}{*}{ Parvovirinae } & \multirow{3}{*}{ Protoparvovirus } & & Canine parvovirus & & & & \\
\hline & & $\begin{array}{c}\text { Carnivore } \\
\text { protoparvovirus } 1\end{array}$ & $\begin{array}{c}2 \\
(\mathrm{CPV}-2 \text { and its } \\
\text { variant } 2 \mathrm{a}, 2 \mathrm{~b}, 2 \mathrm{c})\end{array}$ & Japan & 1993 & $\begin{array}{l}\text { Stool, } \\
\text { blood }\end{array}$ & [13] \\
\hline & & $\begin{array}{c}\text { Carnivore } \\
\text { protoparvovirus } 2 *\end{array}$ & $\begin{array}{c}\text { Feline } \\
\text { bufavirus }(\mathrm{FeBuV})\end{array}$ & Italy & 2017 & $\begin{array}{l}\text { Stool, } \\
\text { respiratory } \\
\text { samples }\end{array}$ & [14] \\
\hline & \multirow{3}{*}{ Bocaparvovirus } & $\begin{array}{c}\text { Carnivore } \\
\text { bocaparvovirus } 3\end{array}$ & $\begin{array}{c}\text { Feline } \\
\text { bocavirus (FBoV-1) }\end{array}$ & $\begin{array}{l}\text { Hong } \\
\text { Kong }\end{array}$ & 2012 & $\begin{array}{l}\text { Stool, urine, } \\
\text { kidney, } \\
\text { blood, } \\
\text { respiratory } \\
\text { samples }\end{array}$ & [15] \\
\hline & & $\begin{array}{c}\text { Carnivore } \\
\text { bocaparvovirus } 4\end{array}$ & $\begin{array}{c}\text { Feline } \\
\text { bocavirus } 2 \\
(\text { FBoV-2) }\end{array}$ & Portugal & 212 & Stool & [16] \\
\hline & & $\begin{array}{c}\text { Carnivore } \\
\text { bocaparvovirus } 5\end{array}$ & $\begin{array}{c}\text { Feline } \\
\text { bocavirus } 3 \\
(\text { FBoV-3) }\end{array}$ & USA & 2014 & Stool & [17] \\
\hline \multirow[t]{2}{*}{ Hamaparvovirinae } & \multirow[t]{2}{*}{ Chaphamaparvovirus } & $\begin{array}{c}\text { Carnivore } \\
\text { chaphamaparvovirus } 1\end{array}$ & $\begin{array}{c}\text { Feline } \\
\text { chaphamaparvovirus } \\
(\text { FeChPV })\end{array}$ & China & 2020 & Stool & {$[18]$} \\
\hline & & Fechavirus * & Fechavirus & Canada & 2020 & Stool & [19] \\
\hline
\end{tabular}

* Tentatively proposed species.

Anorexia, vomiting, diarrhea, neutropenia, and lymphopenia are common in clinically affected cases. Kittens are most severely affected. In utero or neonatal infection can result in cerebellar hypoplasia. Depending on the severity of the clinical signs, mortality ranges from $25 \%$ to $100 \%$. FPL is now diagnosed infrequently by veterinarians in several countries, presumably as a consequence of widespread vaccine use [12,20]. For example, in Australia, there had been no outbreaks of FPL reported even in shelters for over 30 years [12], but multiple outbreaks occurred in eastern Australia between 2014 and 2018 [21]. Infection rates remain high in some unvaccinated cat populations, and the disease occasionally is seen in vaccinated, pedigreed kittens that have been exposed to a high-titer virus challenge $[12,20]$.

In agreement with current ICTV guidelines, parvoviruses are considered members of the same species if their NS1 proteins share more than $85 \%$ amino acid (aa) sequence identity. They can be classified into the same taxon if their protein sequences cluster as a robust monophyletic lineage based on their complete NS1 protein sequence at the subfamily level and on their SF3 helicase domains at the family level. Additionally, NS1 proteins of members of the same genus should share at least $35-40 \%$ aa sequence identity, with a coverage of $>80 \%$ between any two members. Failing the sequence identity-based criteria, common genus affiliation can also be justified based on a similar genome organization, i.e., presence or absence of certain auxiliary-protein-encoding genes, genome length, and/or transcription strategy $[1,2,4,6]$.

There is limited information on the epidemiology and genetic heterogeneity of these new parvoviruses, and it is unclear whether these viruses could play a role as enteric pathogens in cats and what is their impact on feline health. The aim of this review is to provide an update on emerging feline parvoviruses that have most recently been identified in association (or not) with enteric signs. 


\section{Protoparvoviruses}

The species Carnivore protoparvovirus 1, within genus Protoparvovirus (Table 1), includes genetically and antigenically related viruses such as FPV, CPV, and parvoviruses of wild animals, all causing clinically important diseases, especially in young animals [1,3,4,6,22-26].

FPV has been known since 1928 [9,10], while CPV emerged as a dog pathogen in the late 1970s, most likely as a host variant of the feline virus [27] and thanks to an unknown putative adaptive host $[23,28,29]$. Currently, the evolutionary studies and host jumps of protoparvoviruses in carnivores are generating strong scientific interest around the world.

It is known that, among parvoviruses, CPV evolves more rapidly than FPV [30], showing higher rates of nucleotide changes [31-34]. Indeed, a few years after its onset, the original strain CPV-2 gave way to two antigenic variants, $\mathrm{CPV}-2 \mathrm{a}$ and $\mathrm{CPV}-2 \mathrm{~b}[35,36]$. In 2000, a third variant, CPV-2c, was identified in Italy [37] and found to spread quickly in all continents, with the exception of Australia [29,38-50]. Although the main host is the dog (Canis lupus familiaris) [51], CPV variants are able to infect numerous other carnivores, including cats (Felis catus) [24,52,53].

Unlike the original CPV-2, which does not infect cats, its antigenic variants have been widely isolated from the blood $[54,55]$ and feces of cats worldwide, in both natural [13,52,55-62] and experimental [63] infections. CPV was detected in cats for the first time in the late 1980s, when CPV-2a-like strains were isolated from non-symptomatic cats in Japan [13]. Subsequently, CPV was also detected in cats with the identification of $2 b$ strains in the USA [64] and of CPV-2a/2b strains in Germany [52].

In several cases of natural infection, the CPV variants were reported in the feces of healthy cats $[13,33,65,66]$, as a probable outcome of prolonged shedding or subclinical infection $[33,55]$. A longitudinal study, carried out on cats hosted in two shelters, showed a high prevalence of $\mathrm{CPV}$, in the total absence of clinical signs and with prolonged fecal shedding for up to 6 weeks, suggesting a possible role of cats as reservoirs and asymptomatic carriers for $\mathrm{CPV}$ infection [65]. This hypothesis was supported by a more recent study, which detected the DNA of FPV and CPV variants (CPV-2b and $2 c)$ in the white blood cells (WBCs) of asymptomatic cats, despite the presence of specific antibodies against parvoviruses [55].

On the other hand, another study, conducted in Australia in 2018, reported the extremely low prevalence of $\mathrm{CPV}$ fecal shedding in asymptomatic shelter-housed cats, concluding that the fecal spread of CPV by healthy cats could not represent a real risk of infection in mixed cat-dog shelters [67].

Many other studies report CPVs as a cause of clinical signs in cats that are indistinguishable from those induced by FPV $[24,47,54,59-62,68]$, although this virus remains the most common etiological agent of FPL $[52,67,68]$. CPV variants were also identified in nervous tissues, posing the question of the replicative ability of these viruses in differentiated and not mitotically active cells [53,69]. One of the first cases of natural CPV infection in cats occurred in a 1.5-year-old female cat with typical signs of panleukopenia [56]; another case of a 5-month-old kitten with classic presentation of FPL, characterized by depression, fever, dehydration, and marked leukopenia, was associated to CPV-2c infection [62].

Subsequently, CPV variants were retrieved from cats with FPL-like disease in Italy, Germany, USA, Japan, India, Portugal, and Spain [24,47,52,53,55,56,58-61,70,71]

Interestingly, as cats are susceptible to both CPV variants and FPV, superinfection and co-infection with multiple Carnivore protoparvovirus 1 strains may occur, potentially facilitating the recombination and high genetic heterogeneity of these viruses. Indeed, the detection of mixed FPV/CPV infections in cats, associated or not with clinical signs, emphasizes the possible role of cats as a source of new variants of parvoviruses, with concrete problems for the implementation of prophylaxis [55,59-61]. Recently, the ability of FPV to replicate in the dog thymus has been demonstrated in experimental infections [72], but the virus has not been detected in the canine intestine so far.

In 2017, in Italy, a new protoparvovirus strain was identified from cats with or without signs of upper respiratory tract disease and from stool samples of diarrheic animals [14] 
(Table 1). This virus shared more than $99.9 \%$ nt sequence identity of VP2 with canine bufavirus $(\mathrm{CBuV})$, previously detected in a litter of five-month-old puppies during an outbreak of canine infectious respiratory disease (CIRD) in Italy [73]. CBuV displayed low aa identity (19.3-51.4\%) in the NS1 protein to members of the species Carnivore protoparvovirus 1, while the closest relatives to $\mathrm{CBuV}(47.2-51.4 \%$ aa identity in NS1) were protoparvoviruses identified in human and non-human primates, commonly termed bufaviruses (BuVs) [74-76]. In agreement with the new ICTV classification criteria, these canine and feline protoparvoviruses could be considered members of a new species, which has been referred to as Carnivore protoparvovirus 2, within the genus Protoparvovirus, [14,73].

In humans and, more recently, in wild animals (wolves and foxes), BuVs were identified almost exclusively in the enteric tract $[77,78]$. However, investigations in dogs [73,79], monkeys [76], shrews [80], and sea otters [81] suggest possible extraintestinal and/or systemic $\mathrm{BuV}$ infections. In a more recent study conducted in $\mathrm{China}, \mathrm{CBuV}$ s were detected in sera from dogs with signs of CIRD [79]. Similarly, feline strains appear to be part of the feline respiratory virome, since $\mathrm{BuVs}$ have been detected more frequently in respiratory samples than in rectal swabs, with a possible age-related pattern of infection [14].

Accordingly, in domestic carnivore species, a preferential tropism of these viruses for the respiratory tract has been hypothesized, although their identification in the enteric tract of domestic carnivores and, more recently, of wild canids [77] should be further investigated in order to rule out their enteropathogenic role, as well as the possibility that fecal shedding of BuVs represents a strategy of virus persistence in animal populations.

The multi-host nature of viruses belonging to genus Protoparvirus and the ability of some of them to induce severe clinical signs are aspects that must be considered in the implementation of individual and collective prophylaxis plans, in order not only to limit the spread of these viruses between individuals of the same species, but also to prevent the transmission of other carnivore species that share the same environment.

\section{Bocaparvoviruses}

Bocaviruses (BoVs) are members of the genus Bocaparvovirus (subfamily Parvovirinae) that cause disease in various animals and humans, including porcine BoVs [82,83], bovine parvovirus [84], California sea lion BoV [85], bats BoV [86], rabbit BoV [87], rodent BoV [88], pine martens BoV [89], mink BoV [90], canine BoVs [15,91,92], feline BoVs [15-17,93], gorilla BoV [94,95], and human BoVs [96,97], thus suggesting a potentially wide host range of these parvoviruses.

BoVS are unique among parvoviruses since they contain an additional ORF (ORF3), located between the non-structural (ORF1) and structural (ORF2) coding regions of their genome, a 5.5-kb ssDNA (Figure 1). ORF3 encodes for NP1, a highly phosphorylated protein that is not similar to proteins of other parvoviruses and plays a role in RNA processing. NP1 controls the splicing of VP-encoding RNAs and read-through of the proximal polyadenylation [3,98-100].

\section{$5.5 \mathrm{~kb}$ ss DNA}

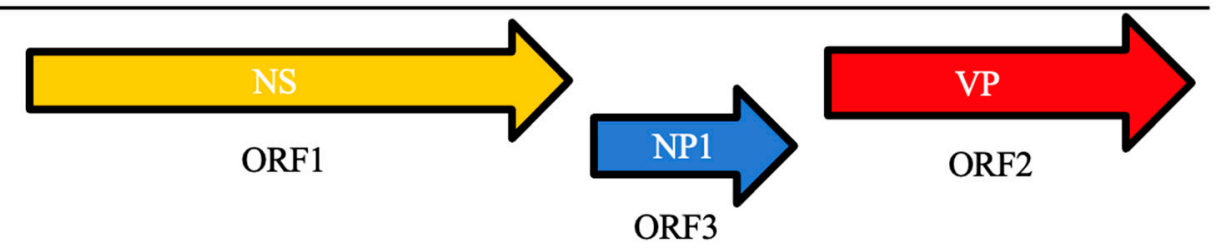

Figure 1. Schematic genome organization of bocaviruses.

Following ICTV classification criteria, BoVs are classified into twenty-five officially recognized species, of which at least five species have been detected in domestic carnivores (Carnivore bocaparvovirus 1-5), while a sixth species (Carnivore bocaparvovirus 6) was found in mink $[3,4,6,90]$. Currently, feline bocaparvoviruses (FBoVs) identified in domestic cats 
are classified within the species Carnivore bocaparvovirus 3 to 5 [15-17] (Table 1). FBoV DNA was detected for the first time in 2012, using molecular tools, in feces, nasal swabs, urine, kidney, and blood collected from stray cats in Hong Kong [15]. The near-complete genomic sequences (5179-5331 nt) were obtained from two fecal samples (HK797F and HK875F) and from a urine sample (HK797U) of two cats. After sequence analysis, the three FBoV genomes showed an identity of $58.6-59.7 \%$ to canine minute virus $[15,91]$.

In agreement with new strict classification criteria, the newly discovered feline parvoviruses have been classified within a species named Carnivore bocaparvovirus 3 (subspecies FBoV-1) $[1,3,4,6]$. Subsequently, using a metagenomics approach on nucleic acids of enriched viral particles from the feces of a single healthy cat in Portugal [16], an additional near-complete bocavirus genome was sequenced (strain POR1). Strain POR1 shares an aa identity of $58 \%$ for NS1 and of $70 \%$ for VP1 with the three FBoVs previously identified in Hong Kong $[15,16]$. Accordingly, strain POR1 has been classified as a distinct species, Carnivore bocaparvovirus 4 (FBoV-2) [16]. A third strain of feline bocavirus (FBoV-3) was detected in 2014 in fecal pools collected from 25 cats from a shelter in California using nextgeneration sequencing (NGS). FBoV-3 has been accepted as a prototype of an additional species, Carnivore bocaparvovirus 5, since it shares an aa sequence identity of $68 \%$ for NS1 and of $76 \%$ for VP1 with the other feline bocavirus strains previously identified [17].

Since then, different genomes of FBoV have been reported in Europe, China, Japan, Thailand, and Canada from the feces of cats with and without clinical signs [16,19,93,101-103]. This suggests that different FBoVs circulate in cats in different geographical areas, without any unambiguous correlation between FBoV genetic diversity and biological properties.

FBoV-1 infection could pose a concrete health risk to cats since it has been associated with enteritis [104,105]. Several studies have shown that FBoV-1 is more likely to be detected in cats with diarrhea than in healthy cats [93,102-104]. In a molecular survey performed in China, FBoV-1 DNA was found in 7.7\% of the feces from cats with severe enteritis, while it was not detected in healthy animals [102]. In another investigation conducted in China, FBoV-1 DNA was evident in $2.8 \%$ of cats with severe enteritis, with a statistically significant association between FBoV-1 infection and the presence of diarrhea [103]. In a more recent study carried out in Thailand, three independent outbreaks of hemorrhagic enteritis in household cats associated with FBoV-1 infection were described [93].

Moreover, the detection of FBoV-1 DNA in multiple tissues, including fecal, urine, blood, respiratory, and kidney samples, collected from stray cats in Hong Kong, suggests a wide tissue tropism [15].

On the other hand, whether FBoV-2 and 3 can play a role in the occurrence of gastroenteritis or other feline diseases remains unclear. Indeed, these viruses were repeatedly found in fecal samples of healthy cats $[16,17]$. In a Japanese study, the FBoV-2 genome was identified in rectal swabs collected from healthy cats $(8.4 \%)$ and from cats with gastroenteritis (11.32\%), without a statistically significant association between viral DNA detection and the presence of clinical signs [101].

In most cases, FBoV DNA was co-detected in cats with other viral pathogens such as FPV [93], fechaviruses [19], rotaviruses, astroviruses, bocaviruses, sakobuviruses, and/or picobirnaviruses $[16,22,101]$, suggesting that FBoV could be considered a common component of the feline fecal virome. Although the role of systemic infection of cats remains undetermined, a pathogenic role of FBoV enteric infection is possible. Synergistic effects of co-infections with other enteric viruses could lead to more severe clinical signs, such as hemorrhagic enteritis [93,102].

Including systematically FBoVs in the diagnostic algorithm of feline viral enteritis, using specific molecular tools, could help us to better understand the enteropathogenic potential of these viruses and the possible correlation between the genetic diversity and the biological proprieties of each different FBoV species. 


\section{Chaphamaparvoviruses}

The genus Chaphamaparvovirus (ChPV) (subfamily Hamaparvovirinae), recently introduced in the family Parvoviridae, includes viruses genetically more related to invertebrateinfecting parvoviruses than to members of the subfamily Parvovirinae. Future detection and characterization of new viruses related to currently recognized members of this proposed taxon might eventually result in splitting the currently recognized single genus into more genera. Currently, however, clustering of these viruses as a single genus is the only common node characterized by significant topology support by both Bayesian and maximum likelihood-based inference [2-4,6].

After the first identification in oropharyngeal swab samples collected from a fruit bat (Eidolon helvum) in Ghana [106], ChPV-like viruses have been reported in several additional animal species [2], including dogs and cats [18,19,107-109]. The first description of ChPV in domestic carnivores occurred in the USA in 2017, where an NGS approach was used on the feces of two dogs with hemorrhagic diarrhea of unknown etiology [107]. Later, viruses genetically close to the American canine ChPV strains were found in the feces of dogs and cats in China and Italy $[18,108,109]$. In agreement with ICTV classification criteria, all strains of canine and feline $(\mathrm{FeChPV})$ origin have been segregated in the new species referred to as Carnivore chaphamaparvovirus 1 (CaChPV-1), sharing an overall aa identity of $98.6-99.8 \%$ in the NS1 protein [4] (Table 1). Recently, a new feline ChPV strain was recovered from feline feces during an outbreak of vomiting and diarrhea in a multifacility feline shelter in Canada using a viral metagenomic approach [19]. NS1 protein shared $76.0-77.0 \%$ aa identity with CaChPV-1 strains previously detected in feline and canine samples, so that this strain was allocated in another species named Fechavirus $[4,19]$ (Table 1).

In a recent case-control study carried out in Italy, FeChPV has been identified from fecal and respiratory samples of cats, displaying a correlation with acute gastroenteritis [110]. Since the Italian strains shared more than $97.7 \%$ aa identity in the NS1 protein with Canadian prototype viruses, they have been clustered into a monophyletic, welldistinguished species (Fechavirus) with respect to the FeChPV strains found in China and currently classified as the species Carnivore chaphamaparvovirus $1[2,18,19,110]$. Feciavirus infection has been correlated with acute gastroenteritis, whereas no correlation has been found with upper respiratory tract disease [110].

Interestingly, in the first report on the detection of ChPV-related parvovirus in domestic cats in China, there was an attempt to isolate the virus on cell cultures, with the observation of a cytopathic effect only up to the fifth generation of cultured cells that were coinfected by FeChPV and FPV [18]. All subsequent studies were mainly focused on the detection of ChPV DNA in cats using molecular approaches, aiming to highlight the epidemiology and genetic heterogeneity of these viruses and to find possible correlations between the presence of viral DNA and clinical signs. To date, however, the information regarding ChPV in cats is still limited and further studies are needed to investigate important aspects such as the host range in vitro (the ability of these viruses to adapt to the in vitro growth is still unclear) and the possibility of detection by immunohistology in the tissues of infected cats $[18,19,110]$.

The potential clinical impact of ChPVs on feline health and their possible role as primary enteric/respiratory pathogens remain to be clarified $[19,110]$. Indeed, ChPVs DNA was often co-detected in cats with other viral pathogens such as FBoV (Li Y. et al., 2020), feline coronavirus, kobuvirus, and norovirus [110]. Further epidemiological data collected from independent studies in other geographical areas are required to confirm the preliminary findings available so far and assess whether these new parvoviruses can be considered a stable and common component of the host virome or, on the contrary, they play a role in the development of disease in infected cats. 


\section{Conclusions}

In the last twenty years, using new molecular techniques and metagenomic approaches for the screening of feline samples, several lineages and species of parvoviruses have been found in association with enteric and/or respiratory disease in cats. Although several aspects concerning epidemiology and virus-host interaction remain to be clarified, some pieces of evidence suggest these emerging feline parvoviruses may act as primary causative pathogens or synergistic agents in the occurrence of clinical signs in cats. Each emerging parvovirus should be included systematically in diagnostic algorithms for detection of feline viral pathogens, chiefly for cats with enteric and/or respiratory disease. Moreover, large structured epidemiological studies and experimental infections might help clarify any possible association of emerging parvoviruses with the occurrence of disease and their distribution in the feline population.

Interestingly, the multi-species circulation of many of these emerging parvoviruses could represent a concrete problem when devising prophylactic measures in animals living in the same environment and, in particular, in mixed cat-dog shelters and veterinary clinics.

Vaccines are not available for emerging parvoviruses of cats, so that vaccination protocols cannot prevent the spread of these viruses, for some of which the cat could represent the host reservoir. Therefore, in order to limit inter- and intra-species spread as much as possible, prophylaxis plans should consider strong disinfection protocols and physical separation, particularly in those facilities housing both dogs and cats.

Author Contributions: Conceptualization, N.D. and V.M.; writing-original draft preparation, P.C.; supervision, C.B.; writing - review and editing, all authors. All authors have read and agreed to the published version of the manuscript.

Funding: This research received no external funding.

Conflicts of Interest: The authors declare no conflict of interest.

\section{References}

1. Cotmore, S.F.; Agbandje-McKenna, M.; Canuti, M.; Chiorini, J.A.; Eis-Hubinger, A.M.; Hughes, J.; Mietzsch, M.; Modha, S.; Ogliastro, M.; Penzes, J.J.; et al. ICTV Virus Taxonomy Profile: Parvoviridae. J. Gen. Virol. 2019, 100, 367-368. [CrossRef]

2. Penzes, J.J.; de Souza, W.M.; Agbandje-McKenna, M.; Gifford, R.J. An Ancient Lineage of Highly Divergent Parvoviruses Infects both Vertebrate and Invertebrate Hosts. Viruses 2019, 11, 525. [CrossRef] [PubMed]

3. ICTV_-International Committee on Taxonomy of Viruses. Available online: https://talk.ictvonline.org/ictv-reports/ictv_online_ report/ssdna-viruses/w/parvoviridae (accessed on 4 March 2021).

4. Penzes, J.J.; Soderlund-Venermo, M.; Canuti, M.; Eis-Hubinger, A.M.; Hughes, J.; Cotmore, S.F.; Harrach, B. Reorganizing the family Parvoviridae: A revised taxonomy independent of the canonical approach based on host association. Arch. Virol. 2020, 165, 2133-2146. [CrossRef] [PubMed]

5. Reed, A.P.; Jones, E.V.; Miller, T.J. Nucleotide sequence and genome organization of canine parvovirus. J. Virol. 1988, 62, 266-276. [CrossRef]

6. $\quad$ Chung, H.C.; Kim, S.J.; Nguyen, V.G.; Shin, S.; Kim, J.Y.; Lim, S.K.; Park, Y.H.; Park, B. New genotype classification and molecular characterization of canine and feline parvoviruses. J. Vet. Sci. 2020, 21, e43. [CrossRef] [PubMed]

7. Parrish, C.R. Emergence, natural history, and variation of canine, mink, and feline parvoviruses. Adv. Virus Res. 1990, 38, 403-450. [CrossRef]

8. MacLachlan, N.J.; Dubovi, E.J. (Eds.) Parvoviridae. In Fenner's Veterinary Virology, 5th ed.; Academic Press: Cambridge, MA, USA, 2017; pp. 245-257. [CrossRef]

9. Verge, J.; Christoforoni, N. La gastroenterite infectieuse des chats; est-elle due à un virus filtrable? CR Seances Soc. Biol. Fil. 1928, $99,312$.

10. Hindle, E.; Findlay, G.M. Studies on feline distemper. Comp. Pathol. Ther. 1932, 45, 11-26. [CrossRef]

11. Ndiana, L.A.; Lanave, G.; Desario, C.; Berjaoui, S.; Alfano, F.; Puglia, I.; Fusco, G.; Colaianni, M.L.; Vincifori, G.; Camarda, A.; et al. Circulation of diverse protoparvoviruses in wild carnivores, Italy. Transbound. Emerg. Dis. 2020. [CrossRef]

12. Barrs, V.R. Feline Panleukopenia: A Re-emergent Disease. Vet Clin. North Am. Small Anim. Pract. 2019, 49, 651-670. [CrossRef]

13. Mochizuki, M.; Harasawa, R.; Nakatani, H. Antigenic and genomic variabilities among recently prevalent parvoviruses of canine and feline origin in Japan. Vet. Microbiol. 1993, 38, 1-10. [CrossRef]

14. Diakoudi, G.; Lanave, G.; Capozza, P.; Di Profio, F.; Melegari, I.; Di Martino, B.; Pennisi, M.G.; Elia, G.; Cavalli, A.; Tempesta, M.; et al. Identification of a novel parvovirus in domestic cats. Vet. Microbiol. 2019, 228, 246-251. [CrossRef] 
15. Lau, S.K.P.; Woo, P.C.Y.; Yeung, H.C.; Teng, J.L.L.; Wu, Y.; Bai, R.; Fan, R.Y.Y.; Chan, K.H.; Yuen, K.Y. Identification and characterization of bocaviruses in cats and dogs reveals a novel feline bocavirus and a novel genetic group of canine bocavirus. $J$. Gen. Virol. 2012, 93, 1573-1582. [CrossRef]

16. Ng, T.F.; Mesquita, J.R.; Nascimento, M.S.; Kondov, N.O.; Wong, W.; Reuter, G.; Knowles, N.J.; Vega, E.; Esona, M.D.; Deng, X.; et al. Feline fecal virome reveals novel and prevalent enteric viruses. Vet. Microbiol. 2014, 171, 102-111. [CrossRef] [PubMed]

17. Zhang, W.; Li, L.; Deng, X.; Kapusinszky, B.; Pesavento, P.A.; Delwart, E. Faecal virome of cats in an animal shelter. J. Gen. Virol. 2014, 95, 2553-2564. [CrossRef]

18. Ji, J.; Hu, W.; Liu, Q.; Zuo, K.; Zhi, G.; Xu, X.; Kan, Y.; Yao, L.; Xie, Q. Genetic Analysis of Cachavirus-Related Parvoviruses Detected in Pet Cats: The First Report From China. Front Vet. Sci. 2020, 7, 580836. [CrossRef] [PubMed]

19. Li, Y.; Gordon, E.; Idle, A.; Altan, E.; Seguin, M.A.; Estrada, M.; Deng, X.; Delwart, E. Virome of a Feline Outbreak of Diarrhea and Vomiting Includes Bocaviruses and a Novel Chapparvovirus. Viruses 2020, 12, 506. [CrossRef]

20. Greene, E.C. Feline enteric viral infections. In Infectious Diseases of the Dog and Cat, 4th ed.; Greene, C.E., Ed.; Linda Duncan: St. Louis, MO, USA, 2012; pp. 80-88.

21. Jenkins, E.; Davis, C.; Carrai, M.; Ward, M.P.; O’Keeffe, S.; van Boeijen, M.; Beveridge, L.; Desario, C.; Buonavoglia, C.; Beatty, J.A.; et al. Feline Parvovirus Seroprevalence Is High in Domestic Cats from Disease Outbreak and Non-Outbreak Regions in Australia. Viruses 2020, 12, 320. [CrossRef] [PubMed]

22. Di Martino, B.; Di Profio, F.; Melegari, I.; Marsilio, F. Feline Virome-A Review of Novel Enteric Viruses Detected in Cats. Viruses 2019, 11, 908. [CrossRef]

23. Decaro, N.; Buonavoglia, C. Canine parvovirus-a review of epidemiological and diagnostic aspects, with emphasis on type 2c. Vet. Microbiol. 2012, 155, 1-12. [CrossRef]

24. Decaro, N.; Buonavoglia, D.; Desario, C.; Amorisco, F.; Colaianni, M.L.; Parisi, A.; Terio, V.; Elia, G.; Lucente, M.S.; Cavalli, A.; et al. Characterisation of canine parvovirus strains isolated from cats with feline panleukopenia. Res. Vet. Sci. 2010, 89, 275-278. [CrossRef] [PubMed]

25. Decaro, N.; Buonavoglia, C.; Barrs, V.R. Canine parvovirus vaccination and immunisation failures: Are we far from disease eradication? Vet. Microbiol. 2020, 247, 108760. [CrossRef] [PubMed]

26. Decaro, N.; Elia, G.; Buonavoglia, C. Challenge studies for registration of canine core vaccines: Is it time to update the European Pharmacopeia? Vet. Microbiol. 2020, 244, 108659. [CrossRef] [PubMed]

27. Truyen, U. Evolution of canine parvovirus-A need for new vaccines? Vet. Microbiol. 2006, 117, 9-13. [CrossRef]

28. Decaro, N.; Buonavoglia, C. Canine parvovirus post-vaccination shedding: Interference with diagnostic assays and correlation with host immune status. Vet. J. 2017, 221, 23-24. [CrossRef] [PubMed]

29. Nandi, S.; Chidri, S.; Kumar, M.; Chauhan, R.S. Occurrence of canine parvovirus type 2c in the dogs with haemorrhagic enteritis in India. Res. Vet. Sci. 2010, 88, 169-171. [CrossRef]

30. Decaro, N.; Desario, C.; Miccolupo, A.; Campolo, M.; Parisi, A.; Martella, V.; Amorisco, F.; Lucente, M.S.; Lavazza, A.; Buonavoglia, C. Genetic analysis of feline panleukopenia viruses from cats with gastroenteritis. J. Gen. Virol. 2008, 89, 2290-2298. [CrossRef]

31. Shackelton, L.A.; Parrish, C.R.; Truyen, U.; Holmes, E.C. High rate of viral evolution associated with the emergence of carnivore parvovirus. Proc. Natl. Acad. Sci. USA 2005, 102, 379-384. [CrossRef]

32. Pereira, C.A.; Leal, E.S.; Durigon, E.L. Selective regimen shift and demographic growth increase associated with the emergence of high-fitness variants of canine parvovirus. Infect. Genet. Evol. 2007, 7, 399-409. [CrossRef]

33. Hoelzer, K.; Parrish, C.R. The emergence of parvoviruses of carnivores. Vet. Res. 2010, 41, 39. [CrossRef] [PubMed]

34. Decaro, N.; Desario, C.; Parisi, A.; Martella, V.; Lorusso, A.; Miccolupo, A.; Mari, V.; Colaianni, M.L.; Cavalli, A.; Di Trani, L.; et al. Genetic analysis of canine parvovirus type 2c. Virology 2009, 385, 5-10. [CrossRef]

35. Parrish, C.R.; Aquadro, C.F.; Strassheim, M.L.; Evermann, J.F.; Sgro, J.Y.; Mohammed, H.O. Rapid antigenic-type replacement and DNA sequence evolution of canine parvovirus. J. Virol. 1991, 65, 6544-6552. [CrossRef] [PubMed]

36. Parrish, C.R.; O'Connell, P.H.; Evermann, J.F.; Carmichael, L.E. Natural variation of canine parvovirus. Science 1985, 230, 1046-1048. [CrossRef] [PubMed]

37. Buonavoglia, C.; Martella, V.; Pratelli, A.; Tempesta, M.; Cavalli, A.; Buonavoglia, D.; Bozzo, G.; Elia, G.; Decaro, N.; Carmichael, L. Evidence for evolution of canine parvovirus type 2 in Italy. J. Gen. Virol. 2001, 82, 3021-3025. [CrossRef]

38. Martella, V.; Cavalli, A.; Pratelli, A.; Bozzo, G.; Camero, M.; Buonavoglia, D.; Narcisi, D.; Tempesta, M.; Buonavoglia, C. A canine parvovirus mutant is spreading in Italy. J. Clin. Microbiol. 2004, 42, 1333-1336. [CrossRef] [PubMed]

39. Nakamura, M.; Tohya, Y.; Miyazawa, T.; Mochizuki, M.; Phung, H.T.; Nguyen, N.H.; Huynh, L.M.; Nguyen, L.T.; Nguyen, P.N.; Nguyen, P.V.; et al. A novel antigenic variant of Canine parvovirus from a Vietnamese dog. Arch. Virol. 2004, 149, $2261-2269$. [CrossRef] [PubMed]

40. Decaro, N.; Desario, C.; Addie, D.D.; Martella, V.; Vieira, M.J.; Elia, G.; Zicola, A.; Davis, C.; Thompson, G.; Thiry, E.; et al. The study molecular epidemiology of canine parvovirus, Europe. Emerg. Infect. Dis. 2007, 13, 1222-1224. [CrossRef]

41. Decaro, N.; Elia, G.; Martella, V.; Desario, C.; Campolo, M.; Trani, L.D.; Tarsitano, E.; Tempesta, M.; Buonavoglia, C. A real-time PCR assay for rapid detection and quantitation of canine parvovirus type 2 in the feces of dogs. Vet. Microbiol. 2005, 105, 19-28. [CrossRef] 
42. Decaro, N.; Martella, V.; Desario, C.; Bellacicco, A.L.; Camero, M.; Manna, L.; d'Aloja, D.; Buonavoglia, C. First detection of canine parvovirus type 2c in pups with haemorrhagic enteritis in Spain. J. Vet Med. B Infect. Dis. Vet Public Health 2006, 53, 468-472. [CrossRef]

43. Perez, R.; Francia, L.; Romero, V.; Maya, L.; Lopez, I.; Hernandez, M. First detection of canine parvovirus type 2c in South America. Vet. Microbiol. 2007, 124, 147-152. [CrossRef]

44. Hong, C.; Decaro, N.; Desario, C.; Tanner, P.; Pardo, M.C.; Sanchez, S.; Buonavoglia, C.; Saliki, J.T. Occurrence of canine parvovirus type 2c in the United States. J. Vet. Diagn. Investig. 2007, 19, 535-539. [CrossRef]

45. Calderon, M.G.; Mattion, N.; Bucafusco, D.; Fogel, F.; Remorini, P.; La Torre, J. Molecular characterization of canine parvovirus strains in Argentina: Detection of the pathogenic variant CPV2c in vaccinated dogs. J. Virol. Methods 2009, 159, 141-145. [CrossRef]

46. Joao Vieira, M.; Silva, E.; Oliveira, J.; Luisa Vieira, A.; Decaro, N.; Desario, C.; Muller, A.; Carvalheira, J.; Buonavoglia, C.; Thompson, G. Canine parvovirus 2c infection in central Portugal. J. Vet. Diagn. Investig. 2008, 20, 488-491. [CrossRef] [PubMed]

47. Charoenkul, K.; Tangwangvivat, R.; Janetanakit, T.; Boonyapisitsopa, S.; Bunpapong, N.; Chaiyawong, S.; Amonsin, A. Emergence of canine parvovirus type 2c in domestic dogs and cats from Thailand. Transbound. Emerg. Dis. 2019, 66, 1518-1528. [CrossRef] [PubMed]

48. Chiang, S.Y.; Wu, H.Y.; Chiou, M.T.; Chang, M.C.; Lin, C.N. Identification of a novel canine parvovirus type 2c in Taiwan. Virol. J. 2016, 13, 160. [CrossRef] [PubMed]

49. Zhao, Z.; Liu, H.; Ding, K.; Peng, C.; Xue, Q.; Yu, Z.; Xue, Y. Occurrence of canine parvovirus in dogs from Henan province of China in 2009-2014. BMC Vet. Res. 2016, 12, 138. [CrossRef] [PubMed]

50. Kelman, M.; Norris, J.M.; Barrs, V.R.; Ward, M.P. A history of canine parvovirus in Australia: What can we learn? Aust. Vet. J. 2020, 98, 504-510. [CrossRef]

51. Greene, E.C.; Decaro, N. Canine viral enteritis. In Infectious Diseases of the Dog and Cat, 4th ed.; Greene, C.E., Ed.; Linda Duncan: St. Louis, MO, USA, 2012; pp. 67-79.

52. Truyen, U.; Platzer, G.; Parrish, C.R. Antigenic type distribution among canine parvoviruses in dogs and cats in Germany. Vet. Rec. 1996, 138, 365-366. [CrossRef]

53. Decaro, N.; Desario, C.; Amorisco, F.; Losurdo, M.; Colaianni, M.L.; Greco, M.F.; Buonavoglia, C. Canine parvovirus type 2c infection in a kitten associated with intracranial abscess and convulsions. J. Feline Med. Surg. 2011, 13, 231-236. [CrossRef]

54. Ikeda, Y.; Mochizuki, M.; Naito, R.; Nakamura, K.; Miyazawa, T.; Mikami, T.; Takahashi, E. Predominance of canine parvovirus (CPV) in unvaccinated cat populations and emergence of new antigenic types of CPVs in cats. Virology 2000, 278, 13-19. [CrossRef] [PubMed]

55. Balboni, A.; Bassi, F.; De Arcangeli, S.; Zobba, R.; Dedola, C.; Alberti, A.; Battilani, M. Molecular analysis of carnivore Protoparvovirus detected in white blood cells of naturally infected cats. BMC Vet. Res. 2018, 14, 41. [CrossRef]

56. Mochizuki, M.; Horiuchi, M.; Hiragi, H.; San Gabriel, M.C.; Yasuda, N.; Uno, T. Isolation of canine parvovirus from a cat manifesting clinical signs of feline panleukopenia. J. Clin. Microbiol. 1996, 34, 2101-2105. [CrossRef]

57. Gamoh, K.; Shimazaki, Y.; Makie, H.; Senda, M.; Itoh, O.; Inoue, Y. The pathogenicity of canine parvovirus type-2b, FP84 strain isolated from a domestic cat, in domestic cats. J. Vet. Med. Sci. 2003, 65, 1027-1029. [CrossRef]

58. Gamoh, K.; Shimazaki, Y.; Senda, M.; Makie, H.; Itoh, O.; Inoue, Y. Antigenic type distribution of parvovirus isolated from domestic cats in Japan. Vet. Rec. 2003, 153, 751-752.

59. Battilani, M.; Balboni, A.; Ustulin, M.; Giunti, M.; Scagliarini, A.; Prosperi, S. Genetic complexity and multiple infections with more Parvovirus species in naturally infected cats. Vet. Res. 2011, 42, 43. [CrossRef]

60. Battilani, M.; Balboni, A.; Giunti, M.; Prosperi, S. Co-infection with feline and canine parvovirus in a cat. Vet. Ital. 2013, 49, 127-129. [PubMed]

61. Battilani, M.; Scagliarini, A.; Ciulli, S.; Morganti, L.; Prosperi, S. High genetic diversity of the VP2 gene of a canine parvovirus strain detected in a domestic cat. Virology 2006, 352, 22-26. [CrossRef] [PubMed]

62. Miranda, C.; Parrish, C.R.; Thompson, G. Canine parvovirus 2c infection in a cat with severe clinical disease. J. Vet. Diagn. Invest. 2014, 26, 462-464. [CrossRef] [PubMed]

63. Nakamura, K.; Sakamoto, M.; Ikeda, Y.; Sato, E.; Kawakami, K.; Miyazawa, T.; Tohya, Y.; Takahashi, E.; Mikami, T.; Mochizuki, M. Pathogenic potential of canine parvovirus types 2a and 2c in domestic cats. Clin. Diagn. Lab. Immunol. 2001, 8, 663-668. [CrossRef]

64. Truyen, U.; Evermann, J.F.; Vieler, E.; Parrish, C.R. Evolution of canine parvovirus involved loss and gain of feline host range. Virology 1996, 215, 186-189. [CrossRef]

65. Clegg, S.R.; Coyne, K.P.; Dawson, S.; Spibey, N.; Gaskell, R.M.; Radford, A.D. Canine parvovirus in asymptomatic feline carriers. Vet. Microbiol. 2012, 157, 78-85. [CrossRef]

66. Marenzoni, M.L.; Antognoni, M.T.; Baldelli, F.; Miglio, A.; Stefanetti, V.; Desario, C.; Di Summa, A.; Buonavoglia, C.; Decaro, N. Detection of parvovirus and herpesvirus DNA in the blood of feline and canine blood donors. Vet. Microbiol. 2018, $224,66-69$. [CrossRef]

67. Byrne, P.; Beatty, J.A.; Slapeta, J.; Corley, S.W.; Lyons, R.E.; McMichael, L.; Kyaw-Tanner, M.T.; Dung, P.T.; Decaro, N.; Meers, J.; et al. Shelter-housed cats show no evidence of faecal shedding of canine parvovirus DNA. Vet. J. 2018, 239, 54-58. [CrossRef] [PubMed]

68. Stuetzer, B.; Hartmann, K. Feline parvovirus infection and associated diseases. Vet. J. 2014, 201, 150-155. [CrossRef] [PubMed] 
69. Url, A.; Truyen, U.; Rebel-Bauder, B.; Weissenbock, H.; Schmidt, P. Evidence of parvovirus replication in cerebral neurons of cats. J. Clin. Microbiol. 2003, 41, 3801-3805. [CrossRef] [PubMed]

70. Calatayud, O.; Esperon, F.; Velarde, R.; Oleaga, A.; Llaneza, L.; Ribas, A.; Negre, N.; de la Torre, A.; Rodriguez, A.; Millan, J. Genetic characterization of Carnivore Parvoviruses in Spanish wildlife reveals domestic dog and cat-related sequences. Transbound. Emerg. Dis. 2020, 67, 626-634. [CrossRef]

71. Mukhopadhyay, H.K.; Nookala, M.; Thangamani, N.R.; Sivaprakasam, A.; Antony, P.X.; Thanislass, J.; Srinivas, M.V.; Pillai, R.M. Molecular characterisation of parvoviruses from domestic cats reveals emergence of newer variants in India. J. Feline Med. Surg. 2017, 19, 846-852. [CrossRef] [PubMed]

72. Truyen, U.; Parrish, C.R. Canine and feline host ranges of canine parvovirus and feline panleukopenia virus: Distinct host cell tropisms of each virus in vitro and in vivo. J. Virol. 1992, 66, 5399-5408. [CrossRef]

73. Martella, V.; Lanave, G.; Mihalov-Kovacs, E.; Marton, S.; Varga-Kugler, R.; Kaszab, E.; Di Martino, B.; Camero, M.; Decaro, N.; Buonavoglia, C.; et al. Novel Parvovirus Related to Primate Bufaviruses in Dogs. Emerg. Infect. Dis. 2018, 24, 1061-1068. [CrossRef]

74. Phan, T.G.; Vo, N.P.; Bonkoungou, I.J.; Kapoor, A.; Barro, N.; O’Ryan, M.; Kapusinszky, B.; Wang, C.; Delwart, E. Acute diarrhea in West African children: Diverse enteric viruses and a novel parvovirus genus. J. Virol. 2012, 86, 11024-11030. [CrossRef]

75. Yahiro, T.; Wangchuk, S.; Tshering, K.; Bandhari, P.; Zangmo, S.; Dorji, T.; Tshering, K.; Matsumoto, T.; Nishizono, A.; Soderlund-Venermo, M.; et al. Novel human bufavirus genotype 3 in children with severe diarrhea, Bhutan. Emerg. Infect. Dis. 2014, 20, 1037-1039. [CrossRef]

76. Handley, S.A.; Thackray, L.B.; Zhao, G.; Presti, R.; Miller, A.D.; Droit, L.; Abbink, P.; Maxfield, L.F.; Kambal, A.; Duan, E.; et al. Pathogenic simian immunodeficiency virus infection is associated with expansion of the enteric virome. Cell 2012, 151, 253-266. [CrossRef]

77. Melegari, I.; Di Profio, F.; Palombieri, A.; Sarchese, V.; Diakoudi, G.; Robetto, S.; Orusa, R.; Marsilio, F.; Banyai, K.; Martella, V.; et al. Molecular detection of canine bufaviruses in wild canids. Arch. Virol. 2019, 164, 2315-2320. [CrossRef]

78. Vaisanen, E.; Paloniemi, M.; Kuisma, I.; Lithovius, V.; Kumar, A.; Franssila, R.; Ahmed, K.; Delwart, E.; Vesikari, T.; Hedman, K.; et al. Epidemiology of two human protoparvoviruses, bufavirus and tusavirus. Sci. Rep. 2016, 6, 39267. [CrossRef]

79. Sun, W.; Zhang, S.; Huang, H.; Wang, W.; Cao, L.; Zheng, M.; Yin, Y.; Zhang, H.; Lu, H.; Jin, N. First identification of a novel parvovirus distantly related to human bufavirus from diarrheal dogs in China. Virus Res. 2019, 265, 127-131. [CrossRef]

80. Sasaki, M.; Orba, Y.; Anindita, P.D.; Ishii, A.; Ueno, K.; Hang'ombe, B.M.; Mweene, A.S.; Ito, K.; Sawa, H. Distinct Lineages of Bufavirus in Wild Shrews and Nonhuman Primates. Emerg. Infect. Dis. 2015, 21, 1230-1233. [CrossRef]

81. Siqueira, J.D.; Ng, T.F.; Miller, M.; Li, L.; Deng, X.; Dodd, E.; Batac, F.; Delwart, E. Endemic Infection of Stranded Southern Sea Otters (Enhydra Lutris Nereis) with Novel Parvovirus, Polyomavirus, and Adenovirus. J. Wildl. Dis. 2017, 53, 532-542. [CrossRef] [PubMed]

82. Cheng, W.X.; Li, J.S.; Huang, C.P.; Yao, D.P.; Liu, N.; Cui, S.X.; Jin, Y.; Duan, Z.J. Identification and nearly full-length genome characterization of novel porcine bocaviruses. PLoS ONE 2010, 5, e13583. [CrossRef] [PubMed]

83. Shan, T.; Lan, D.; Li, L.; Wang, C.; Cui, L.; Zhang, W.; Hua, X.; Zhu, C.; Zhao, W.; Delwart, E. Genomic characterization and high prevalence of bocaviruses in swine. PLoS ONE 2011, 6, e17292. [CrossRef]

84. Chen, K.C.; Shull, B.C.; Moses, E.A.; Lederman, M.; Stout, E.R.; Bates, R.C. Complete nucleotide sequence and genome organization of bovine parvovirus. J. Virol. 1986, 60, 1085-1097. [CrossRef] [PubMed]

85. Li, L.; Shan, T.; Wang, C.; Cote, C.; Kolman, J.; Onions, D.; Gulland, F.M.; Delwart, E. The fecal viral flora of California sea lions. J. Virol. 2011, 85, 9909-9917. [CrossRef] [PubMed]

86. Wu, Z.; Ren, X.; Yang, L.; Hu, Y.; Yang, J.; He, G.; Zhang, J.; Dong, J.; Sun, L.; Du, J.; et al. Virome analysis for identification of novel mammalian viruses in bat species from Chinese provinces. J. Virol. 2012, 86, 10999-11012. [CrossRef]

87. Lanave, G.; Martella, V.; Farkas, S.L.; Marton, S.; Feher, E.; Bodnar, L.; Lavazza, A.; Decaro, N.; Buonavoglia, C.; Banyai, K. Novel bocaparvoviruses in rabbits. Vet. J. 2015, 206, 131-135. [CrossRef]

88. Lau, S.K.; Yeung, H.C.; Li, K.S.; Lam, C.S.; Cai, J.P.; Yuen, M.C.; Wang, M.; Zheng, B.J.; Woo, P.C.; Yuen, K.Y. Identification and genomic characterization of a novel rat bocavirus from brown rats in China. Infect. Genet. Evol. 2017, 47, 68-76. [CrossRef]

89. Van den Brand, J.M.; van Leeuwen, M.; Schapendonk, C.M.; Simon, J.H.; Haagmans, B.L.; Osterhaus, A.D.; Smits, S.L. Metagenomic analysis of the viral flora of pine marten and European badger feces. J. Virol. 2012, 86, 2360-2365. [CrossRef]

90. Yang, S.; Wang, Y.; Li, W.; Fan, Z.; Jiang, L.; Lin, Y.; Fu, X.; Shen, Q.; Sun, Z.; Wang, X.; et al. A novel bocavirus from domestic mink, China. Virus Genes 2016, 52, 887-890. [CrossRef]

91. Binn, L.N.; Lazar, E.C.; Eddy, G.A.; Kajima, M. Recovery and characterization of a minute virus of canines. Infect. Immun. 1970, 1, 503-508. [CrossRef] [PubMed]

92. Kapoor, A.; Mehta, N.; Dubovi, E.J.; Simmonds, P.; Govindasamy, L.; Medina, J.L.; Street, C.; Shields, S.; Lipkin, W.I. Characterization of novel canine bocaviruses and their association with respiratory disease. J. Gen. Virol. 2012, 93, 341-346. [CrossRef] [PubMed]

93. Piewbang, C.; Kasantikul, T.; Pringproa, K.; Techangamsuwan, S. Feline bocavirus-1 associated with outbreaks of hemorrhagic enteritis in household cats: Potential first evidence of a pathological role, viral tropism and natural genetic recombination. Sci. Rep. 2019, 9, 16367. [CrossRef] [PubMed] 
94. Kapoor, A.; Mehta, N.; Esper, F.; Poljsak-Prijatelj, M.; Quan, P.L.; Qaisar, N.; Delwart, E.; Lipkin, W.I. Identification and characterization of a new bocavirus species in gorillas. PLOS ONE 2010, 5, e11948. [CrossRef] [PubMed]

95. Sharp, C.P.; LeBreton, M.; Kantola, K.; Nana, A.; Diffo Jle, D.; Djoko, C.F.; Tamoufe, U.; Kiyang, J.A.; Babila, T.G.; Ngole, E.M.; et al. Widespread infection with homologues of human parvoviruses B19, PARV4, and human bocavirus of chimpanzees and gorillas in the wild. J. Virol. 2010, 84, 10289-10296. [CrossRef]

96. Allander, T.; Tammi, M.T.; Eriksson, M.; Bjerkner, A.; Tiveljung-Lindell, A.; Andersson, B. Cloning of a human parvovirus by molecular screening of respiratory tract samples. Proc. Natl. Acad. Sci. USA 2005, 102, 12891-12896. [CrossRef]

97. Vicente, D.; Cilla, G.; Montes, M.; Perez-Yarza, E.G.; Perez-Trallero, E. Human bocavirus, a respiratory and enteric virus. Emerg. Infect. Dis. 2007, 13, 636-637. [CrossRef]

98. Fasina, O.O.; Dong, Y.; Pintel, D.J. NP1 Protein of the Bocaparvovirus Minute Virus of Canines Controls Access to the Viral Capsid Genes via Its Role in RNA Processing. J. Virol. 2016, 90, 1718-1728. [CrossRef] [PubMed]

99. Fasina, O.O.; Stupps, S.; Figueroa-Cuilan, W.; Pintel, D.J. Minute Virus of Canines NP1 Protein Governs the Expression of a Subset of Essential Nonstructural Proteins via Its Role in RNA Processing. J. Virol. 2017, 91, e00260-17. [CrossRef] [PubMed]

100. Zou, W.; Cheng, F.; Shen, W.; Engelhardt, J.F.; Yan, Z.; Qiu, J. Nonstructural Protein NP1 of Human Bocavirus 1 Plays a Critical Role in the Expression of Viral Capsid Proteins. J. Virol. 2016, 90, 4658-4669. [CrossRef]

101. Takano, T.; Takadate, Y.; Doki, T.; Hohdatsu, T. Genetic characterization of feline bocavirus detected in cats in Japan. Arch. Virol. 2016, 161, 2825-2828. [CrossRef]

102. Liu, C.; Liu, F.; Li, Z.; Qu, L.; Liu, D. First report of feline bocavirus associated with severe enteritis of cat in Northeast China, 2015. J. Vet. Med. Sci. 2018, 80, 731-735. [CrossRef]

103. Yi, S.; Niu, J.; Wang, H.; Dong, G.; Zhao, Y.; Dong, H.; Guo, Y.; Wang, K.; Hu, G. Detection and genetic characterization of feline bocavirus in Northeast China. Virol. J. 2018, 15, 125. [CrossRef]

104. Wang, Y.; Li, W.; Guo, X.; Zhang, D.; Sun, J.; Fu, Z.; Liu, G.; Li, Y.; Jiang, S. Development of SYBR Green I-based polymerase chain reaction for feline bocavirus 1 detection. 3 Biotech 2021, 11, 61. [CrossRef] [PubMed]

105. Wang, Y.; Sun, J.; Guo, X.; Zhang, D.; Cui, Y.; Li, W.; Liu, G.; Li, Y.; Jiang, S. TaqMan-based real-time polymerase chain reaction assay for specific detection of bocavirus-1 in domestic cats. Mol. Cell. Probes 2020, 53, 101647. [CrossRef]

106. Baker, K.S.; Leggett, R.M.; Bexfield, N.H.; Alston, M.; Daly, G.; Todd, S.; Tachedjian, M.; Holmes, C.E.; Crameri, S.; Wang, L.F.; et al. Metagenomic study of the viruses of African straw-coloured fruit bats: Detection of a chiropteran poxvirus and isolation of a novel adenovirus. Virology 2013, 441, 95-106. [CrossRef] [PubMed]

107. Fahsbender, E.; Altan, E.; Seguin, M.A.; Young, P.; Estrada, M.; Leutenegger, C.; Delwart, E. Chapparvovirus DNA Found in 4\% of Dogs with Diarrhea. Viruses 2019, 11, 398. [CrossRef] [PubMed]

108. Hu, W.; Liu, Q.; Chen, Q.; Ji, J. Molecular characterization of Cachavirus firstly detected in dogs in China. Infect. Genet. Evol. 2020, 85, 104529. [CrossRef] [PubMed]

109. Palombieri, A.; Di Profio, F.; Lanave, G.; Capozza, P.; Marsilio, F.; Martella, V.; Di Martino, B. Molecular detection and characterization of Carnivore chaphamaparvovirus 1 in dogs. Vet. Microbiol. 2020, 251, 108878. [CrossRef]

110. Di Profio, F.; Sarchese, V.; Palombieri, A.; Fruci, P.; Massirio, I.; Martella, V.; Fulvio, M.; Di Martino, B. Feline chaphamaparvovirus in cats with enteritis and upper respiratory tract disease. Transbound. Emerg. Dis. 2021. [CrossRef] [PubMed] 